\title{
Occurrence, human health and ecotoxicological risk assessment of pesticides in surface waters of the River Nile's Rosetta Branch, Egypt
}

Fawzy Ismail Eissa ( $\nabla$ fawzy.eissa@yahoo.com )

Al-Azhar University - Egypt https://orcid.org/0000-0003-3611-4854

\section{Mahmoud Al-Sisi}

Agricultural Research Center

Khaled Ghanem

Al-Azhar University

\section{Research Article}

Keywords: Pesticides, River Nile, Spatiotemporal variations, Risk quotient, THQ.

Posted Date: March 1st, 2021

DOl: https://doi.org/10.21203/rs.3.rs-224766/v1

License: (c) (i) This work is licensed under a Creative Commons Attribution 4.0 International License. Read Full License 


\section{Abstract}

In Egypt, the shortage of freshwater resources and their pollution constitutes a growing concern. Therefore, the objectives of this study were to (i) monitor the occurrence and spatiotemporal variations of 100 pesticides in surface water samples collected monthly (from July 2018 to June 2019) from El-Rahawy, Sabal, and Tala sampling sites along the Rosetta branch of the River Nile in Egypt, (ii) identify potential noncarcinogenic health risks for the local people through the lifetime consumption of contaminated drinking water, and (iii) perform an ecological risk assessment of aquatic organisms upon exposure to pesticides detected in surface waters based on the risk quotients (RQs) method. Of the 100 pesticides analyzed, 22 belonging to 11 chemical families were detected, and $75.5 \%$ of surface water samples were contaminated with one or more pesticide residues. The most frequently detected pesticide was malathion (57\%), followed by chlorpyrifos (54\%), atrazine (23\%), and carbendazim (20\%). Spatial distribution showed that the ElRahawy site had the highest pesticide load $(38.47 \mu \mathrm{g} / \mathrm{L})$, and Sabal had the lowest $(16.29 \mu \mathrm{g} / \mathrm{L})$. Temporal variations revealed that the highest total pesticide concentrations were detected in summer $(27.98 \mu \mathrm{g} / \mathrm{L})$ compared to spring $(23.16 \mu \mathrm{g} / \mathrm{L})$, winter $(19.18 \mu \mathrm{g} / \mathrm{L})$, and autumn $(11.85 \mu \mathrm{g} / \mathrm{L})$. For non-carcinogenic risks of pesticides detected in surface water, the target hazard quotient (THQ) values were less than one. This implies that there is no potential human risk from exposure to drinking water at the sites under study. However, 13 pesticides presented high-risk quotients $(R Q>1)$, posing potential ecological risks to aquatic organisms.

\section{Introduction}

The River Nile flows through 11 African countries, including Egypt, before discharging into the Mediterranean Sea. In Cairo, the river is divided into two branches, the Rosetta and Damietta, which form the Nile Delta. Due to population growth, rapid urbanization and industrialization, and extensive agriculture, the demand for irrigation, domestic water supply, and industrial water supply from the Rosetta Nile Branch continues to grow (NBI, 2005). The Rosetta branch receives enormous amounts of contaminated water daily from numerous sources, including industrial, agricultural, and municipal wastewater, and feed waste from fish cages. All such sources cause severe negative impacts on the aquatic environment (Abbassy, 2018). The use of pesticides in agriculture and residential areas involves their unintentional releases to adjacent nontarget ecosystems such as rivers (Schulz, 2004). Surface waters are more vulnerable to pesticides in intensive agricultural areas, constituting a major concern for human water consumption. Residues of pesticides in river systems are not only a threat to human health by means of water and fish consumption but also a threat to aquatic species (Zheng et al., 2016).

Monitoring pollutants in the River Nile is essential to provide quantitative data on dominant pollutants, identify their origins and environmental fate, comply with regulations, contend with human and environmental health issues, and enable advanced treatment technologies for accurate targeting (Eissa et al., 2020). Despite the importance of regular pesticide monitoring programs, most studies to date (Dahshan et al., 2016; Shalaby et al., 2018; El-Alfy et al., 2019) have focused on the analysis of limited numbers and few classes of pesticides with infrequent sampling. Also, these studies have not considered human health or ecotoxicological risk assessment of pesticides in surface water. 
Chronic ingestion of pollutants into humans above a safe threshold can have adverse effects and pose noncarcinogenic risks such as neurological disorders and hepatorenal alterations (Farmer et al., 2011). The target hazard quotient (THQ), established by the US EPA, is widely used to assess the potential noncarcinogenic human health risks associated with long-term exposure to contaminated water through the oral route (US EPA, 1989). A useful indicator of risk levels linked with exposure to contaminants can be found in the THQ-based risk assessment method (Wang et al., 2012).

The ecological risk assessment of pesticides is described in terms of environmental exposure and ecotoxicological impacts. The potential aquatic ecotoxicological risk assessment of detected pesticide residues was calculated using the risk quotient $(\mathrm{RQ})$ method, which is the ratio of the measured environmental concentration (MEC) of a single pesticide to the predicted no-effect concentration (PNEC) (Palma et al., 2014).

Therefore, the objectives of this study were to (i) monitor the occurrence and spatiotemporal variations of 100 pesticide belonging to different chemical classes in surface water samples collected monthly (from July 2018 to June 2019) for the first time from El-Rahawy, Sabal, and Tala sampling sites situated along the Rosetta Branch of the River Nile in Egypt, (ii) identify potential non-carcinogenic health risks for the local people through the lifetime consumption of contaminated drinking water, and (iii) perform an ecological risk assessment of aquatic organisms upon exposure to pesticides detected in surface waters based on the risk quotients (RQs) method.

\section{Materials And Methods}

\section{Study area and sampling campaign}

The sampling strategy was adopted based on the presence of three drains (El-Rahawy, Sabal, and Tala) that receive untreated, partially treated, and/or treated wastewater from wastewater treatment plants (WWTPs) that eventually discharge their effluents directly into the Rosetta Branch of the River Nile. Monitoring surveys were conducted at three sampling points along the Rosetta Branch over 12 sampling periods from July 2018 to June 2019. In the three sampling sites, 144 surface water samples were collected in duplicate as follows: $1 \mathrm{~km}$ before (upstream) and $1 \mathrm{~km}$ after (downstream) the outlet of (1) the El-Rahawy drain (Giza Governorate; coordinates of $30^{\circ} 12^{\prime} 26.21^{\prime \prime} \mathrm{N}$ and $31^{\circ} 1^{\prime} 58.90^{\prime \prime} \mathrm{E}$ ), (2) the Sabal drain (Minoufiya Governorate; coordinates of $30^{\circ} 32^{\prime} 13.47^{\prime \prime} \mathrm{N}$ and $30^{\circ} 51^{\prime} 07.09^{\prime \prime} \mathrm{E}$ ) and (3) the Tala drain (Kafr El-Zayat, Gharbiya Governorate; coordinates of $30^{\circ} 49^{\prime} 01.74^{\prime \prime} \mathrm{N}$ and $30^{\circ} 48^{\prime} 47.77^{\prime \prime} \mathrm{E}$ ), as described in our previous study (Eissa et al., 2020) and shown in Fig. 1. A complete list of pesticides as target pollutants, their recovery rates, and coefficient of variation at various standard levels and limits of quantification (LOQ) are provided in the Supplementary Material (Table S1).

Surface water samples (sampled at a depth of about $50 \mathrm{~cm}$ from the middle section of the Rosetta Branch) were collected in $2.5 \mathrm{~L}$ amber glass bottles. The bottles were filled to the seal, left no space for air bubbles, labeled, and transferred in an icebox to the Central Laboratory of Residue Analysis of Pesticides and Heavy Metals in Food in Giza. Upon arrival, water samples were immediately vacuum filtered using a glass fiber filter (GC-50, diameter: $47 \mathrm{~mm}$; pore size: $0.5 \mu \mathrm{m}$, Advantec) to remove suspended particles. Each filter was 
then washed with $5 \mathrm{~mL}$ of methanol, which was added to the filtrate. All samples were refrigerated at $\pm 4{ }^{\circ} \mathrm{C}$ until extraction.

\section{Extraction of pesticide residues}

Pesticides were extracted from surface water samples according to Rocha et al. (2012) with some modifications. Oasis HLB cartridges were sequentially washed with $5 \mathrm{~mL}$ of ethyl acetate followed by $5 \mathrm{~mL}$ of methanol and $10 \mathrm{~mL}$ of deionized water at a $2 \mathrm{~mL} / \mathrm{min}$ flow rate. Surface water samples $(500 \mathrm{~mL})$ were loaded into solid-phase extraction (SPE) cartridges at a constant flow rate of $5 \mathrm{~mL} / \mathrm{min}$. After passing the sample, cartridges were dried under vacuum for 30 minutes. The adsorbed pesticides were then eluted with $10 \mathrm{~mL}$ of ethyl acetate into $10 \mathrm{ml}$ tubes at a speed of $1 \mathrm{~mL} / \mathrm{min}$. Four $\mathrm{mL}$ of the eluate was transferred and evaporated under a stream of nitrogen and taken up in $2 \mathrm{~mL}$ of acetonitrile before injecting into the LC$\mathrm{MS} / \mathrm{MS}$ system. Another $4 \mathrm{~mL}$ of the eluate was transferred and evaporated under a stream of nitrogen and taken up in $2 \mathrm{~mL}$ of ethyl acetate before injecting into GC-MS/MS.

\section{Gas chromatography-tandem mass spectrometry (GC/MS-MS) analysis}

As described in our previous study (Eissa et al., 2020), we used an Agilent 7890A gas chromatography system tailored with a 7000B triple quadrupole Agilent mass spectrometer. The column was a DB-35MS Ultra Inert Capillary Column (35\% Phenyl-65\% dimethylpolysiloxane, $30 \mathrm{~m}$ length $\times 0.18 \mathrm{~mm}$ internal diameter $\times 0.25 \mu \mathrm{m}$ film thickness, Agilent Technologies). The GC oven temperature program started at 70 ${ }^{\circ} \mathrm{C}$ for $1.3 \mathrm{~min}$ and rose to $150{ }^{\circ} \mathrm{C}$ at $70{ }^{\circ} \mathrm{C} / \mathrm{min}$. It was then raised to $270{ }^{\circ} \mathrm{C}$ at $12{ }^{\circ} \mathrm{C} / \mathrm{min}$ and finally to 310 ${ }^{\circ} \mathrm{C}$ at $18{ }^{\circ} \mathrm{C} / \mathrm{min}$ and held for $6.3 \mathrm{~min}$ for a total run time of $21 \mathrm{~min}$ per sample. The inlet temperature was $250^{\circ} \mathrm{C}$, the injection volume was $1 \mu \mathrm{L}$, and the injection was performed in splitless mode. Helium was used as the carrier gas at a constant flow rate of $0.7 \mathrm{ml} / \mathrm{min}$, and nitrogen was used as the collision gas. Electron impact mode was used, and the ionization energy was 70 electron-volts $(\mathrm{eV})$. The ion source temperature was $320^{\circ} \mathrm{C}$, the GC-MS/MS interface temperature was $320^{\circ} \mathrm{C}$, and the quadrupole temperature was $180^{\circ} \mathrm{C}$. MassHunter software was used for instrument control and data acquisition/processing.

\section{Liquid chromatography-tandem mass spectrometry (LC/MS-MS) analysis}

As described in our previous study (Eissa et al., 2020), we used the LC-MS/MS system consisting of an Agilent 1200 Series HPLC connected to an API 4000 Qtrap MS/MS from Applied Biosystems (Foster City, CA, USA). The separation was performed on an Agilent C18 ZORBAX Eclipse XDB column with a length of 150 $\mathrm{mm}$, an inner diameter of $4.6 \mathrm{~mm}$, and a particle size of $5.0 \mu \mathrm{m}$. The temperature of the column was $40{ }^{\circ} \mathrm{C}$, and the volume of injection was $5 \mu \mathrm{L}$. The separation was performed by gradient elution between two components; A: $10 \mathrm{mM}$ of ammonium formate solution in methanol: water $(1: 9 \mathrm{v} / \mathrm{v})$ and $B$ : methanol. The initial flow rate was $0.5 \mathrm{ml} / \mathrm{min}$, starting with $100 \%$ of component $A$, gradually changing to $5 \% \mathrm{~A}(95 \% \mathrm{~B})$ over $6 \mathrm{~min}$, and held constant for $17 \mathrm{~min}$ at a flow rate of $0.3 \mathrm{ml} / \mathrm{min}$. After this $23 \mathrm{~min}$ run time, a $2 \mathrm{~min}$ post time was followed using the initial $100 \%$ of $A$ at a flow rate of $0.5 \mathrm{ml} / \mathrm{min}$. The MS/MS analysis was performed using electrospray ionization (ESI) in the positive ion mode in multiple reaction monitoring mode (MRM). The following source and gas parameters were used: $450{ }^{\circ} \mathrm{C}$ temperature; 25 psi curtain gas; 
medium collision gas; $5000 \mathrm{~V}$ ion spray voltage; 1, 40 psi ion source gas; and 2, 40 psi ion source gas. Analyst Software version 1.6. was used for instrument control and data acquisition/processing.

\section{Quality assurance}

All analytical methods and instruments were entirely validated as part of a laboratory quality control and assurance system (ISO/IEC 17025:2005). They were audited and accredited by the Centre for Metrology and Accreditation, Finnish Accreditation Service (FINAS), Helsinki, Finland. In order to estimate extraction efficiency, the blank and spiked samples were analyzed according to the methods mentioned above. The mean recovery of the selected pesticides in surface water samples ranged from 70 to $120 \%$. The coefficient of variation at various standard levels was $<20 \%$, while the limit of quantification (LOQ) was $0.05 \mu \mathrm{g} / \mathrm{L}$ for pesticide residues. These data are provided in Table S1 (Supplementary Material).

\section{Human risk assessment}

The potential non-carcinogenic health risks associated with the consumption of contaminated water with pesticide residues were assessed based on the target hazard quotient (THQ), which was estimated using the following equation (USEPA, 1989):

$T H Q=(E F \times E D \times F I R \times C) /(R f D \times B W \times A T)$

where $\mathrm{EF}$ is the exposure frequency (365 days/year), $\mathrm{ED}$ is the exposure duration (70 years; equivalent to the average human lifetime), FIR is the water ingestion rate $(2000 \mathrm{~mL} /$ person/day), $\mathrm{C}$ is the pesticide concentration in water (mg/L), RfD is the oral reference dose (USEPA, 2019) (Table 3), BW is the body weight (70 kg/person), and AT is the average time for non-carcinogens (365 days/year $\times \mathrm{ED}$ ). If the THQ value is $\geq 1$, exposed individuals may experience health risks by consuming contaminated water. Therefore, interventions and protective measures need to be taken.

\section{Ecotoxicological risk assessment}

The potential aquatic ecotoxicological risk was assessed based on the risk quotient (RQ) method (ECC, 2003) for detected pesticide residues in surface water. This is the ratio between the measured environmental concentration (MEC) of a single pesticide and the predicted no-effect concentration (PNEC) (RQ = MEC/PNEC) (Palma et al., 2014). For calculating PNEC, the lowest no observed effect concentration (NOEC) values were used. In the absence of NOEC, the median effective concentration $\left(\mathrm{EC}_{50}\right)$ or the median lethal concentration $\left(\mathrm{LC}_{50}\right)$ values, taken from the pesticide properties database (Lewis et al., 2016), were used.

The PNEC values were estimated by dividing the NOEC or the $\mathrm{EC}_{50}$ or $\mathrm{LC}_{50}$ values of the most sensitive species by an appropriate assessment factor (AF) for the three trophic levels (algae, Daphnia sp., and fish) used. According to the European Commission's Technical Guidance Document on Risk Assessment: (i) an AF of 1000 is used when at least one short-term assay is available at one trophic level; (ii) an AF of 100 is used when data are available from a single long-term assay of either fish or zooplankton; and (iii) AFs of 50 and 10 are used when two and three long-term assays are available, respectively. Thus, we determined each 
pesticide ecological risk for the aquatic ecosystem at each sampling site, using the mean detected concentrations of the pesticides.

\section{Results And Discussion}

\section{Spatiotemporal distribution of pesticide residues in surface water along the Rosetta Nile branch}

Of the 100 pesticides analyzed, 22 pesticides (12 insecticides, six fungicides, two herbicides, one acaricide, and one breakdown product) belonging to 11 chemical families were detected. Overall, $75.5 \%$ of all surface water samples ( $69 \%$ of the upstream and $82 \%$ of the downstream samples) were contaminated with one or more pesticide residues, as shown in Tables 1 and 2 .

Regarding the number of pesticides detected per category in all surface water samples, insecticides were the most frequently detected pesticides ( $72 \%)$, followed by herbicides $(27 \%)$, fungicides $(24 \%)$, and acaricides $(5 \%)$.

With regards to the pesticide families, the organophosphorus pesticides (OPPs) were the most frequently detected group found in $68 \%$ of the total surface water samples. This was followed by triazines (23\%) and benzimidazoles $(20 \%)$, while carbamates and neonicotinoids were similar $(7 \%)$. Organochlorine and pyrethroid pesticides displayed the same detection frequency $(5 \%)$, followed by benzoylureas $(2 \%)$, and finally, anilinopyrimidines, carboxamides, and phthalimides, which all exhibited the same detection frequency $(1 \%)$. The overall frequency of OPPs detection may be due to the widespread use of these compounds in Egyptian agriculture due to their efficiency and low cost.

The detection frequency $(\%)$ and mean concentrations $(\mu \mathrm{g} / \mathrm{L})$ of the most frequently detected pesticide compounds in all surface water samples were malathion $(57 \%$ and $0.42 \mu \mathrm{g} / \mathrm{L})$, followed by chlorpyrifos ( $54 \%$ and $0.183 \mu \mathrm{g} / \mathrm{L})$, atrazine $(23 \%$ and $0.084 \mu \mathrm{g} / \mathrm{L})$, carbendazim $(20 \%$ and $0.082 \mu \mathrm{g} / \mathrm{L})$, phenthoate $(15 \%$ and $1.63 \mu \mathrm{g} / \mathrm{L}$ ), diazinon ( $14 \%$ and $0.257 \mu \mathrm{g} / \mathrm{L})$, chlorpropham $(7 \%$ and $0.131 \mu \mathrm{g} / \mathrm{L})$, and imidacloprid $(7 \%$ and $0.312 \mu \mathrm{g} / \mathrm{L}$ ). In addition, permethrin, heptenophos, and dicofol exhibited the same detection frequency $(5 \%)$, with mean concentrations of $0.666,0.103$, and $0.083 \mu \mathrm{g} / \mathrm{L}$, respectively. In this study, the highest pesticide concentrations were $6.04 \mu \mathrm{g} / \mathrm{L}$ for phenthoate measured downstream of Sabal in the spring and $5.1 \mu \mathrm{g} / \mathrm{L}$ for malathion measured at El-Rahawy in the summer. The detection of banned pesticides in surface water samples indicates their persistence or illegal use in agricultural activities.

Of the 144 analyzed surface water samples, $18,24,12,10,4,2$, and $4 \%$ were contaminated with 1, 2, 3, 4, 5, 6 , and 7 pesticide compounds, respectively. Of the 144 surface water samples, $24 \%$ contained residues $₫ 0.1$ $\mu \mathrm{g} / \mathrm{L}$ (ranging from below LOQ to $0.08 \mu \mathrm{g} / \mathrm{L}$ ), $32 \%$ contained residues $\geq 0.1 \mu \mathrm{g} / \mathrm{L}$ (ranging from 0.1 to 0.47 $\mu \mathrm{g} / \mathrm{L}$ ), $6 \%$ contained residues $\geq 0.5 \mu \mathrm{g} / \mathrm{L}$ (ranging from 0.5 to $0.94 \mu \mathrm{g} / \mathrm{L}$ ), and $15 \%$ contained residues $>1$ $\mu \mathrm{g} / \mathrm{L}$ (ranging from 1.02 to $9.6 \mu \mathrm{g} / \mathrm{L}$ ). The pesticide load found at the Rosetta Branch occurs through various transportation routes, including surface water runoff, leaching, erosion, spray drift, drain outflow, and agricultural, residential, and industrial effluent discharge (Eissa et al., 2020). 
The spatial distribution of the detected pesticides in surface water samples along the Rosetta Branch of the River Nile revealed that El-Rahawy had the highest sum of all pesticide concentrations with $38.47 \mu \mathrm{g} / \mathrm{L}$ ( 4.15 $\mu \mathrm{g} / \mathrm{L}$ in the upstream and $34.32 \mu \mathrm{g} / \mathrm{L}$ in the downstream samples), followed by Tala with $27.41 \mu \mathrm{g} / \mathrm{L}(11.23$ $\mu \mathrm{g} / \mathrm{L}$ in the upstream and $16.18 \mu \mathrm{g} / \mathrm{L}$ in the downstream samples), and Sabal with $16.29 \mu \mathrm{g} / \mathrm{L}(3.5 \mu \mathrm{g} / \mathrm{L}$ in the upstream and $12.79 \mu \mathrm{g} / \mathrm{L}$ in the downstream samples). Furthermore, $50 \%$ of El-Rahawy samples were contaminated with the highest number of pesticides (18 compounds). For comparison, $88 \%$ of the Sabal and Tala samples were contaminated with 13 and 10 pesticides, respectively. Moreover, downstream surface water samples contained more pesticides in terms of number and concentration than those collected from upstream sampling sites. In particular, surface water downstream of the El-Rahawy sampling site showed relatively higher levels of pesticide residues than Tala and Sabal due to receiving primary treated wastewater from the Abu-Rawash wastewater treatment plant (WWTP) through the El-Rahawy drain. This is considered the main cause of water quality deterioration at the River Nile's Rosetta Branch. KöckSchulmeyer et al. (2013) found high levels of pesticides in WWTP effluents, even in WWTPs with tertiary treatment, despite the common belief that this treatment produces water with adequate quality for use in various fields. Furthermore, conventional urban WWTPs have not been originally designed to remove pesticides. Therefore, the efficient removal of pesticides depends on many factors, such as the specificity of the pesticides and the employed treatment methods (Deblonde et al., 2011).

Based on temporal variations, the highest total pesticide concentration detected for 14 pesticides in the summer was $27.98 \mu \mathrm{g} / \mathrm{L}(0.43 \mu \mathrm{g} / \mathrm{L}$ in the upstream and $27.55 \mu \mathrm{g} / \mathrm{L}$ in the downstream samples) compared to 8 pesticides in the spring that was $23.16 \mu \mathrm{g} / \mathrm{L}(6.68 \mu \mathrm{g} / \mathrm{L}$ in the upstream and $16.48 \mu \mathrm{g} / \mathrm{L}$ in the downstream samples), 15 pesticides in the winter that was equal to $19.18 \mu \mathrm{g} / \mathrm{L}(8 \mu \mathrm{g} / \mathrm{L}$ in the upstream and $11.18 \mu \mathrm{g} / \mathrm{L}$ in the downstream samples), and 12 pesticides in the autumn that amounted to $11.85 \mu \mathrm{g} / \mathrm{L}$ $(3.77 \mu \mathrm{g} / \mathrm{L}$ in the upstream and $8.08 \mu \mathrm{g} / \mathrm{L}$ in the downstream samples). Meanwhile, during summer, the ElRahawy samples recorded the highest total pesticide concentration equal to $23.61 \mu \mathrm{g} / \mathrm{L}(0.2 \mu \mathrm{g} / \mathrm{L}$ in the upstream and $23.41 \mu \mathrm{g} / \mathrm{L}$ in the downstream samples). Likewise, samples collected from the El-Rahawy area during autumn were the most contaminated with a total pesticide concentration of $7.91 \mu \mathrm{g} / \mathrm{L}(2.55$ $\mu \mathrm{g} / \mathrm{L}$ in the upstream and $5.36 \mu \mathrm{g} / \mathrm{L}$ in the downstream samples). Conversely, during winter and spring, the Tala samples contained the highest total pesticide concentration equal to $10.71 \mu \mathrm{g} / \mathrm{L}(5.84 \mu \mathrm{g} / \mathrm{L}$ in the upstream and $4.87 \mu \mathrm{g} / \mathrm{L}$ in the downstream samples) and $12.69 \mu \mathrm{g} / \mathrm{L}(4.83 \mu \mathrm{g} / \mathrm{L}$ in the upstream and 7.86 $\mu \mathrm{g} / \mathrm{L}$ in the downstream samples), respectively. Seasonal differences in pesticide residues can be attributed to the additional impact of urban and industrial activities on neighboring activities that coexist with agricultural activities. Elevated pesticide levels in the summer may also be due to partitioning from their reservoirs accumulated in sediments.

These findings are partially consistent with previous studies in other rivers around the world. For example, Gao et al. (2009) found malathion in $43.5 \%$ of surface water samples collected in 2003 and 2004 from seven major river basins and three major internal river drainage areas in China. Fadaei et al. (2012) showed that surface water samples of the Babolrood River in Iran were contaminated by malathion and diazinon at mean concentrations of 55.7 to $75.9 \mu \mathrm{g} / \mathrm{L}$ and from 77.6 to $101.6 \mu \mathrm{g} / \mathrm{L}$, respectively. Their results also showed that the amount of detectable OPPs in the water samples diminished in cold weather. Sangchan et al. (2014) revealed that chlorpyrifos was frequently present in water samples $(75 \%)$ collected from the Mae 
Sa river in Thailand. Montuori et al. (2015) showed the presence of nine organophosphate pesticides at concentrations between 5.58 and $39.25 \mathrm{ng} / \mathrm{L}$ in water samples from the Sarno River in Italy. Ccanccapa et al. (2016) indicated that chlorpyrifos, diazinon, and carbendazim were the most frequent pesticides in the water samples of the Ebro River in Spain (found in 95,95 , and $70 \%$ of the samples, respectively). Dahshan et al. (2016) detected chlorpyrifos in water samples along the River Nile at a mean concentration of $0.578 \mu \mathrm{g} / \mathrm{L}$. Aisha et al. (2017) found that chlorpyrifos and diazinon were the most abundant pesticides in the surface water of rivers in Lebanon.

Atrazine is a triazine herbicide that is a common surface water contaminant owing to its high application rates and chemical properties (Callicott and Hooper-Bùi, 2019). Although atrazine has been banned since 2003 in the European Union, it is still regularly detected in surface waters in that region (Barchanska et al., 2017). Carbendazim is a benzimidazole fungicide that is widely used in crop protection. It is also frequently applied as a preservative for fiber, leather, rubber, and polymerized materials as well as a preservative for construction materials such as building facades (Coutu et al., 2012). The presence of carbendazim in surface water and wastewater samples has been documented in Denmark (Bollmann et al., 2014), Germany (Launay et al., 2016), and China (Xu et al., 2020). Carbendazim concentrations in the range of 600-6000 $\mathrm{ng} / \mathrm{L}$ have been recorded in particular areas of Spain, where this substance was widely used in agriculture (Masiá et al., 2015). In addition, from 2007 to 2012, carbendazim was the most frequently detected pesticide in the surface waters of Costa Rican river basins (Carazo-Rojas et al., 2018). Merel et al. (2018) suggested that carbendazim in surface water originates primarily from treated municipal wastewater discharge. Moreover, paper and textile industries have been found as new potential sources of carbendazim due to the discharge of their effluents. Chlorpropham is widely applied as a sprout inhibitor in stored potatoes, contaminating the storeroom fabric, atmosphere, soil, and waterways (Douglas et al., 2018). The high residual level of dicofol found in the surface water is associated with its use in agriculture as it is a cheaper pesticide. It has also been identified as an additional source of $o, p^{\prime}$-DDT (Wei et al., 2008). Another study conducted by the U. S. Geological Survey demonstrated that at least one neonicotinoid was found in $53 \%$ of surface water samples collected from rivers across the United States. Here, imidacloprid was the most frequently detected neonicotinoid occurring in $37 \%$ of samples (Hladik and Kolpin, 2016).

\section{Risk assessment of water for human consumption}

The potential health risks of individual pesticides detected in the Rosetta Branch of the River Nile's upstream surface water were assessed using the target hazard quotient, THQ (USEPA, 1989). According to WHO recommendations, each adult should drink 2 Liters of water every day. Assuming that the drinking water treatment plants do not remove pesticides using the conventional treatment techniques (Zheng et al., 2016), calculations were undertaken. Regarding non-carcinogenic risks of the detected pesticides in surface water samples, as shown in Table (3), the THQ values were lower than 1. This implies no potential risk to the human body due to the drinking water exposure in the study areas. Surface water samples from the ElRahawy area showed the highest THQ values, i.e., 0.04 and 0.016 for diazinon and chlorpyrifos, respectively. Likewise, diazinon THQ values were the highest at Tala (0.018) and Sabal (0.017). These results agree with those obtained by Gao et al. (2012) who demonstrated that the non-carcinogenic risk hazard quotient values of the detected OPPs in the Haihe River water were less than one, indicating the health risk caused by these 
compounds was at an acceptable level. Papadakis et al. (2015) showed that pesticides in the northern Greece Rivers pose low potential risks to humans due to exposure to drinking water. Zheng et al. (2016) revealed that the health risk associated with the Jiulong River water consumption in South China was low, despite the river water contained pesticide residues at detectable levels.

\section{Ecotoxicological risk assessment}

The risk quotients (RQs) correlated with exposure to individual pesticides detected in surface water samples were calculated for three representative trophic levels, viz., algae, Daphnia sp., and fish. The average detected concentrations at each site were used to determine the RQ and identify the high-risk sites. These were compared to the levels of concern recorded in the literature (i.e., $R Q \geq 1$ : high-risk; $0.1 \leq R Q<1$ : medium risk; $\mathrm{RQ}<0.1$ : low risk) (Sánchez-Bayo et al., 2002).

Tables 4 to 6 show the ecotoxicological risks of detected pesticides based on their annual average concentrations and risk quotient approach. Of the sites monitored, the El-Rahaway site indicated the highest ecotoxicological risk, followed by Sabal and Tala. Risk quotient (RQ) values revealed high ecotoxicological risks (>1) at all sites for chlorpyrifos, diazinon, malathion, and phenthoate. The highest RQ at the ElRahaway site was for malathion, followed by permethrin, chlorpyrifos, and phenthoate with values of 1158.3, 1155.9, 230, and 211.8, respectively. Of all the pesticides detected at the Sabal and Tala sites, phenthoate displayed the highest RQ at 1047 and 982, respectively. At the Sabal site, high RQ values of $116.7,41.9$, and 35 were also found for malathion, diazinon, and chlorpyrifos, respectively. Regarding the Tala site, high RQ values of $129,79.2,29.5$, and 9.8 were also found for permethrin, malathion, chlorpyrifos, and diazinon, respectively.

The high and unacceptable risks posed by these pesticides are mainly due to their relatively high toxicity to algae, Daphnia sp., and fish. This results in their relatively low PNEC values. Moreover, the increased risks observed also result from the combination of the relatively high MEC values and low PNEC values. This ecotoxicological risk assessment emphasizes that such pesticides $(R Q>1)$ must be prioritized for risk management, mainly because the River Nile is a habitat to numerous species. The high aquatic risk posed by pesticides leads to changes in fish and invertebrate populations in the long term, leading to a decrease in the most vulnerable species and an increase in the most resistant species, resulting in biodiversity loss (Palma et al., 2014; Kuzmanović et al., 2015).

Our findings agree with those of Ccanccapa et al. (2016) who found that detected OPPs posed high risks to algae, daphnia, and fish in the Ebro River in Spain. Wee and Aris (2017) indicated that the overall exposure to chlorpyrifos in the surface water of the Langat River in Malaysia posed a high risk ( $R Q>1)$. Sumon et al. (2018) showed high RQs (> 1) for chlorpyrifos, diazinon, quinalphos, malathion, and fenitrothion in the surface water of different water bodies in northwestern Bangladesh. In some water samples from the Guangzhou waterways in China, permethrin was present at high-risk levels with RQ values greater than 1 ( $\mathrm{Li}$ et al., 2019). Contrarily, RQ values for the pesticides detected in small streams in the European Union (Casado et al., 2019) were lower than the RQs calculated in this study for boscalid (0.01275) and carbendazim (1.279753) but higher for dimethoate (0.248765) and imidacloprid (5.235504). 


\section{Conclusions}

This study presents the first monitoring campaign for 100 pesticides in the Rosetta Branch of the River Nile. This research was performed to assess the occurrence, spatiotemporal distribution, and risk assessment of pesticides. Twenty-two pesticides belonging to 11 chemical families were detected, and $75.5 \%$ of surface water samples were contaminated with one or more pesticide residues. Moreover, downstream surface water samples contained more pesticides in terms of number and concentration than those collected from upstream sampling sites. The THQ values of pesticides detected in surface water samples were lower than one, implying no potential risks to humans through exposure to drinking water in the study sites. However, 13 pesticides showed high-risk quotients $(R Q>1)$, posing a potential ecological risk to aquatic organisms. On the other hand, pesticides typically occur in aquatic ecosystems as a mixture of multiple pesticides rather than individually which require further research on their potential combined ecotoxicological impacts. There is also a need to increase assessments of urban, agricultural, and industrial wastewater released into surface waters and evaluate the treatment efficiency requirements of WWTPs. Hence, regular monitoring is recommended to assess the occurrence and potential sources of the River Nile pollution to define mitigation strategies.

\section{Declarations}

\section{Ethical Approval}

This research article does not contain any studies with human participants or animals performed by any of the authors.

\section{Consent to Participate}

The authors declare consent to participate.

\section{Consent to Publish}

All the authors approved the final manuscript and agreed to its submission to the Environmental Science and Pollution Research.

\section{Authors Contributions}

Fawzy Eissa: study design, data processing, results analysis, writing and editing.

Mahmoud Al-Sisi: samples collecting, analysis, data processing and writing a first draft.

Khaled Ghanem: reviewing the manuscript.

\section{Funding}

No funding was received for conducting this study. 
The authors have no conflicts of interest to declare that are relevant to the content of this research article.

\section{Availability of data and materials}

The datasets used or analyzed during the current study are available from the corresponding author on reasonable request.

\section{Appendix A. Supplementary data}

Supplementary data related to this manuscript can be found at...

\section{References}

Abbassy MMS (2018) Distribution pattern of persistent organic pollutants in aquatic ecosystem at the Rosetta Nile branch estuary into the Mediterranean Sea, North of Delta, Egypt. Mar Pollut Bull 131:115-121. https://doi.org/ 10.1016/j.marpolbul.2018.03.049.

Aisha AA, Hneine W, Mokh S, Devier MH, Budzinski H, Jaber F (2017) Monitoring of 45 pesticides in Lebanese surface water using polar organic chemical integrative sampler (POCIS). Ocean Sci J 52:455-466. https://doi.org/ 10.1007/s12601-017-0041-4.

Barchanska H, Sajdak M, Szczypka K, Swientek A, Tworek M, Kurek M (2017) Atrazine, triketone herbicides, and their degradation products in sediment, soil and surface water samples in Poland. Environ Sci Pollut Res 24:644-658. https://doi.org/ 10.1007/s11356-016-7798-3.

Bollmann UE, Tang C, Eriksson E, Jönsson K, Vollertsen J, Bester K (2014) Biocides in urban wastewater treatment plant influent at dry and wet weather: Concentrations, mass flows and possible sources. Water Res 60:64-74. https://doi.org/ 10.1016/j.watres.2014.04.014.

Callicott K, Hooper-Bùi L (2019) An investigation of environmental concentrations of atrazine, chlorothalonil, and fipronil in a Mississippi River-influenced marsh in southern Louisiana. Microchem J 146:1241-1248. https://doi.org/ 10.1016/j.microc.2019.01.060.

Carazo-Rojas E, Pérez-Rojas G, Pérez-Villanueva M, Chinchilla-Soto C, Chin-Pampillo JS, Aguilar-Mora, P, Alpízar-Marín M, Masís-Mora M, Rodríguez-Rodríguez CE, Vryzas Z (2018) Pesticide monitoring and ecotoxicological risk assessment in surface water bodies and sediments of a tropical agroecosystem. Environ Pollut 241:800-809. https://doi.org/ 10.1016/j.envpol.2018.06.020.

Casado J, Brigden K, Santillo D, Johnston P (2019) Screening of pesticides and veterinary drugs in small streams in the European Union by liquid chromatography high resolution mass spectrometry. Sci Total Environ 670:1204-1225. https://doi.org/ 10.1016/j.scitotenv.2019.03.207.

Ccanccapa A, Masiá A, Navarro-Ortega A, Picó Y, Barceló D (2016) Pesticides in the Ebro River basin: occurrence and risk assessment. Environ Pollut 211:414-424. https://doi.org/ 10.1016/j.envpol.2015.12.059. 
Coutu S, Rota C, Rossi L, Barry DA (2012) Modelling city-scale facade leaching of biocide by rainfall. Water Res 46:3525-3534. https://doi.org/ 10.1016/j.watres.2012.03.064.

Dahshan H, Megahed AM, Abd-Elall AMM, Abd-El-Kader MAG, Nabawy E, Elbana MH (2016) Monitoring of pesticides water pollution-the Egyptian River Nile. J Environ Health Sci Eng 14:15. https://doi.org/ 10.1186/s40201-016-0259-6.

Deblonde T, Cossu-Leguille C, Hartemann P (2011) Emerging pollutants in wastewater: a review of the literature. Int J Hyg Environ Health 214:442-448. https://doi.org/ 10.1016/j.ijheh.2011.08.002.

Douglas L, MacKinnon G, Cook G, Duncan H, Briddon A, Seamark S (2018) Determination of chlorpropham (CIPC) residues, in the concrete flooring of potato stores, using quantitative (HPLC UV/VIS) and qualitative (GCMS) methods. Chemosphere 195:119-124. https://doi.org/ 10.1016/j.chemosphere.2017.12.010.

ECC, 2003. Technical Guidance Document on Risk Assessment. Part II. European Community Commission, Brussels. Belgium.

Eissa F, Ghanem K, Al-Sisi M (2020) Occurrence and human health risks of pesticides and antibiotics in Nile tilapia along the Rosetta Nile branch, Egypt. Toxicol Rep 7:1640-1646.

https://doi.org/10.1016/j.toxrep.2020.03.004

El-Alfy MA, Hasballah AF, Abd El-Hamid HT, El-Zeiny AM (2019) Toxicity assessment of heavy metals and organochlorine pesticides in freshwater and marine environments, Rosetta area, Egypt using multiple approaches. Sustain Environ Res 29:19. https://doi.org/ 10.1186/s42834-019-0020-9.

Fadaei A, Dehghani MH, Nasseri S, Mahvi AH, Rastkari N, Shayeghi M (2012) Organophosphorous pesticides in surface water of Iran. Bull Environ Contam Toxicol 88:867-869. https://doi.org/ 10.1007/s00128-0120568-0.

Farmer JG, Broadway A, Cave MR, Wragg J, Fordyce FM, Graham MC, Ngwenya BT, Bewley RJ (2011) A lead isotopic study of the human bioaccessibility of lead in urban soils from Glasgow, Scotland. Sci Total Environ 409:4958-4965. https://doi.org/ /10.1016/j.scitotenv.2011.08.061.

Gao J, Liu L, Liu X, Lu J, Hao H, Yuan H, Zhou H (2012) The organic contamination survey and health risk assessment of 16 source water reservoirs in Haihe River basin. Water Sci Technol 65:998-1006. https://doi.org/ 10.2166/wst.2012.072.

Gao J, Liu L, Liu X, Zhou H, Lu J, Huang S, Wang Z (2009) The occurrence and spatial distribution of organophosphorous pesticides in Chinese surface water. Bull Environ Contam Toxicol 82:223-229. https://doi.org/ 10.1007/s00128-008-9618-z.

Hladik ML, Kolpin DW (2016) First national-scale reconnaissance of neonicotinoid insecticides in streams across the USA. Environ Chem 13:12-20. https://doi.org/ 10.1071/EN15061. 
Köck-Schulmeyer M, Villagrasa M, de Alda ML, Céspedes-Sánchez R, Ventura F, Barceló D (2013) Occurrence and behavior of pesticides in wastewater treatment plants and their environmental impact. Sci Total Environ 458:466-476. https://doi.org/ 10.1016/j.scitotenv.2013.04.010.

Kuzmanović M, Ginebreda A, Petrović M, Barceló D (2015) Risk assessment based prioritization of 200 organic micropollutants in 4 Iberian rivers. Sci Total Environ 503:289-299. https://doi.org/ 10.1016/j.scitotenv.2014.06.056.

Launay MA, Dittmer U, Steinmetz H (2016) Organic micropollutants discharged by combined sewer overflows-characterisation of pollutant sources and stormwater-related processes. Water Res 104:82-92. https://doi.org/ 10.1016/j.watres.2016.07.068.

Lewis KA, Tzilivakis J, Warner DJ, Green A (2016) An international database for pesticide risk assessments and management. Hum Ecol Risk Assess 22:1050-1064. https://doi.org/ 10.1080/10807039.2015.1133242.

Li WG, Huang DY, Chen D, Wang C, Wei GL (2019) Temporal-spatial distribution of synthetic pyrethroids in overlying water and surface sediments in Guangzhou waterways: potential input mechanisms and ecological risk to aquatic systems. Environ Sci Pollut Res 26:17261-17276. https://doi.org/ 10.1007/s11356-019-05013-4.

Masiá A, Campo J, Navarro-Ortega A, Barceló D, Picó Y (2015) Pesticide monitoring in the basin of Llobregat River (Catalonia, Spain) and comparison with historical data. Sci Total Environ 503: 58-68. https://doi.org/ 10.1016/j.scitotenv.2014.06.095.

Merel S, Benzing S, Gleiser C, Di Napoli-Davis G, Zwiener C (2018) Occurrence and overlooked sources of the biocide carbendazim in wastewater and surface water. Environ Pollut 239:512-521. https://doi.org/ 10.1016/j.envpol.2018.04.040.

Montuori P, Aurino S, Nardone A, Cirillo T, Triassi M (2015) Spatial distribution and partitioning of organophosphates pesticide in water and sediment from Sarno River and Estuary, Southern Italy. Environ Sci Pollut Res 22:8629-8642. https://doi.org/ 10.1007/s11356-014-4016-z.

NBI, 2005. Nile Basin Initiative - Nile Basin water quality monitoring baseline report, Nile Basin National Water Monitoring Baseline Study Quality Report for Egypt - Final, 5/8/05.

http://nile.riverawarenesskit.org/English/NRAK/Resources/Document_centre/WQ_Baseline_report_Egypt.pdf

Palma P, Köck-Schulmeyer M, Alvarenga P, Ledo L, Barbosa IR, De Alda ML, Barceló D (2014) Risk assessment of pesticides detected in surface water of the Alqueva reservoir (Guadiana basin, southern of Portugal). Sci Total Environ 488:208-219. https://doi.org/ 10.1016/j.scitotenv.2014.04.088.

Papadakis EN, Vryzas Z, Kotopoulou A, Kintzikoglou K, Makris KC, Papadopoulou-Mourkidou E (2015) A pesticide monitoring survey in rivers and lakes of northern Greece and its human and ecotoxicological risk assessment. Ecotox Environ Safe 116:1-9. https://doi.org/ 10.1016/j.ecoenv.2015.02.033. 
Rocha MJ, Ribeiro MF, Cruzeiro C, Figueiredo F, Rocha E (2012) Development and validation of a GC-MS method for determination of 39 common pesticides in estuarine water-targeting hazardous amounts in the Douro River estuary. Int J Environ Anal Chem 92:1587-1608. https://doi.org/

10.1080/03067319.2011.581366.

Sánchez-Bayo F, Baskaran S, Kennedy IR (2002) Ecological relative risk (EcoRR): another approach for risk assessment of pesticides in agriculture. Agric Ecosyst Environ 91:37-57. https://doi.org/ 10.1016/S01678809(01)00258-4.

Sangchan W, Bannwarth M, Ingwersen J, Hugenschmidt C, Schwadorf K, Thavornyutikarn P, Pansombat K, Streck T (2014) Monitoring and risk assessment of pesticides in a tropical river of an agricultural watershed in northern Thailand. Environ Monit Assess 186:1083-1099. https://doi.org/ 10.1007/s10661-013-3440-8.

Schulz R (2004) Field studies on exposure, effects, and risk mitigation of aquatic nonpoint-source insecticide pollution. J Environ Qual 33: 419-448. https://doi.org/ 10.2134/jeq2004.4190.

Shalaby SEM, El-Saadany SS, Abo-Eyta AM, Abdel-Satar AM, Al-Afify ADG, Abd El-Gleel WMM (2018) Levels of pesticide residues in water, sediment, and fish samples collected from Nile River in Cairo, Egypt. Environ Forensics 19: 228-238. https://doi.org/ 10.1080/15275922.2018.1519735.

Sumon KA, Rashid H, Peeters ET, Bosma RH, Van den Brink PJ (2018) Environmental monitoring and risk assessment of organophosphate pesticides in aquatic ecosystems of north-west Bangladesh. Chemosphere 206: 92-100. https://doi.org/ 10.1016/j.chemosphere.2018.04.167.

SEPA, 1989. Guidance Manual for Assessing Human Health Risks from Chemically Contaminated, Fish and Shellfish. Environmental Protection Agency, Washington, DC., U.S., EPA-503/8-89-002.

USEPA, 2019. Regional Screening Levels (RSLs)-Generic Tables (accessed October 2019). https://www.epa.gov/risk/regional-screening-levels-rsls-generic-tables

Wang Y, Qiao M, Liu Y, Zhu Y (2012) Health risk assessment of heavy metals in soils and vegetables from wastewater irrigated area, Beijing-Tianjin city cluster, China. J Environ Sci (China) 24: 690-698. https://doi.org/ 10.1016/s1001-0742(11)60833-4.

Wee SY, Aris AZ (2017) Ecological risk estimation of organophosphorus pesticides in riverine ecosystems. Chemosphere 188: 575-581. https://doi.org/ 10.1016/j.chemosphere.2017.09.035.

Wei S, Wang YJCW, Lam JC, Zheng GJ, So MK, Yueng LW, Horii Y, Chen LQ, Yu H, Yamashita N, Lam PK (2008) Historical trends of organic pollutants in sediment cores from Hong Kong. Mar Pollut Bull 57: 758766. https://doi.org/ 10.1016/j.marpolbul.2008.03.008.

Xu L, Granger C, Dong H, Mao Y, Duan S, Li J, Qiang Z (2020) Occurrences of 29 pesticides in the Huangpu River, China: Highest ecological risk identified in Shanghai metropolitan area. Chemosphere 251: 126411. https://doi.org/ 10.1016/j.chemosphere.2020.126411. 
Zheng S, Chen B, Qiu X, Chen M, Ma Z, Yu X (2016) Distribution and risk assessment of 82 pesticides in Jiulong River and estuary in South China. Chemosphere 144:1177-1192. https://doi.org/ 10.1016/j.chemosphere.2015.09.050.

\section{Tables}

Due to technical limitations the Tables are available as a download in the Supplementary Files.

\section{Figures}

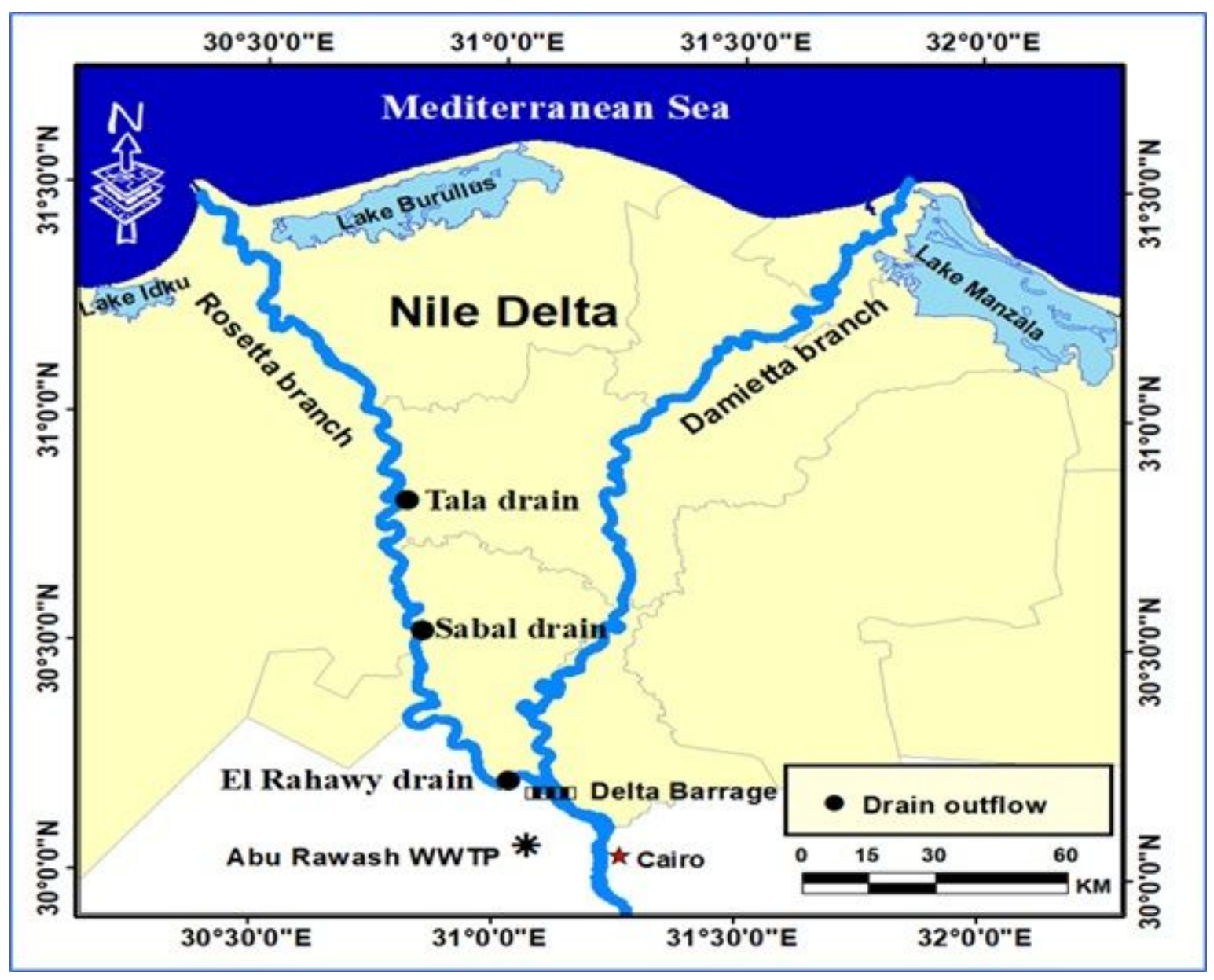

Figure 1

The sampling sites map of surface waters from the River Nile's Rosetta Branch, Egypt.

\section{Supplementary Files}

This is a list of supplementary files associated with this preprint. Click to download.

- Supplementarydata.docx

- Tables.pdf 